\title{
A "VELVET PRISON" WITH CHINESE CHARACTERISTICS: THE CONSTRUCTION OF CULTURE IN POST-1989 CHINA By Keith Goodwin
}

On June 5, 1989, an unidentified man stood alone in front of a row of Chinese tanks. The image, captured by a number of photographers at the scene, was soon scattered throughout Western news reports, which emphasized the power of the individual to stand up to the brute force of an oppressive state - a modern version of David and Goliath. The scene unfolded the day after the Chinese government sent the People's Liberation Army (PLA) into Beijing to disperse civilians who had been protesting in and around Tiananmen Square for weeks. Following a previous failure to disperse the protesters in May, the Chinese government deployed the PLA with live rounds and tanks and ordered that the soldiers clear the square by dawn of June $4 .{ }^{1}$ What ensued was chaos. Beijing was transformed into a virtual war zone with the PLA

1 “The Tank Man," directed by Antony Thomas, Frontline, PBS, April 11, 2006. Available online at http://www.pbs.org/wgbh/pages/frontline/tankman/ (accessed November 7, 2009). 
openly firing upon civilians, wounding 7,000 and killing as many as 2,600 people. $^{2}$

Western democratic nations have often viewed the events that unfolded in 1989 as the brutal suppression of a democratic uprising against authoritarian-communist rule. Emphasizing images like the Goddess of Democracy and placing June 4 in the context of revolutions that occurred in the Eastern Bloc around the same time, however, tends to obscure the fact that the protesters in Beijing sought reform, not revolution. ${ }^{3}$

In the twenty years since June 4, 1989, China has undergone a dramatic economic revolution and transformed itself beyond many people's wildest expectations. While it is tempting to see China's post1989 economic development and the diminishing visibility of the state as a micromanaging entity as a response to the events in Tiananmen Square, it is important to recognize that many of the trends that have surfaced in the past two decades were in motion prior to the 1989 protests. Since taking control of the Chinese Communist Party (CCP) in 1978, Deng Xiaoping had begun a process of "Reform and Opening" that was designed to bring about economic development and material prosperity without sacrificing the political status quo. ${ }^{4}$ Nonetheless, Deng's economic reforms-often characterized as "Socialism with Chinese Characteristics"-allowed an increasing degree of cultural freedom, particularly after his 1992 "Southern Tour." Thus, June 4 is best viewed not as a transformative event in the modernization of China, but as a consequence of tensions inherent in a policy that sought dramatic economic development without the chaos of Mao's Cultural Revolution or a challenge to traditional party authority. This tension continues today.

2 "The Tank Man"; Nicholas D. Kristof, "Beijing Death Toll at Least 300; Army Tightens Control of City but Angry Resistance Goes On,” The New York Times, June 5, 1989.

${ }^{3}$ Jeffrey N. Wasserstrom, "Tiananmen's Shifting Legacy," in China in 2008: A Year of Great Significance, ed. Kate Merkel-Hess, Kenneth L. Pomeranz, and Jeffrey N. Wasserstrom, 135-140 (New York: Rowman and Littlefield Publishers, Inc., 2009), 135.

${ }^{4}$ Liu Kang, Globalization and Cultural Trends in China (Honolulu: University of Hawaii Press, 2004), 1. 
This essay aims to analyze the construction of "Chinese" culture since 1989. Although the events of June 4 will be important to this endeavor, this essay does not intend to illustrate the specific contributions of the Tiananmen Square protests to China's post-1989 cultural development. Instead, this essay looks at the "delicate dance" that has occurred in the last two decades of Chinese history as traditional party rhetoric and government influence have confronted an increasingly pluralistic cultural environment. This is not to say that the previous twenty years have been marked by a simple state-versus-individual conflict. On the contrary, the construction of culture and national identity in post- 1989 China has been highly complex and has been the consequence of conflict and interaction between the state, society, and the market economy.

Certainly the hegemonic influence of the state has played a significant role in defining the limits of the interactions and discourses during this period, but just as the state has sought to impose a coherent cultural identity on members of the Chinese community, groups, individuals, and market forces have similarly affected the development of the state. By examining various trends since 1989, I hope illuminate the ways in which this fluid, and often reciprocal, process of cultural construction has been manifested and demonstrate how it has often undermined the state's dominance in the realm of culture.

\section{China's "VelVet PRISON":}

\section{The Reconstruction of STATE Hegemony}

Although I ultimately argue that the state does not possess a monopoly on culture in post-1989 China, this is not to say that the Chinese government is no longer a dominant player in the process of cultural construction. In fact, the hegemonic power of the state has simply evolved into a more subtle form since 1989. Geremie Barmé's In the Red: On Contemporary Chinese Culture provides a useful line of analysis for understanding this process by applying the work of Hungarian writer Miklós Haraszti-author of The Velvet Prison: Artists Under State Socialism - to contemporary China. Like post-Stalin Eastern Europe, Barmé argues, the state in post-Mao China has tried to 
reformulate the social contract such that "consensus replaces coercion and complicity subverts criticism." In other words, the state has tried to co-opt individuals into a "progressive censorship" that effectively makes them a part of the state rather than a voice of opposition.

While The Velvet Prison focuses specifically on artists, it is equally useful to an understanding of the evolution of society and culture in contemporary China. According to Haraszti, "the velvet prison" is a world in which "[state meddling in the arts] is no longer used to silence opposition to the state but to ensure that intellectuals will more effectively perform their proper role." Consequently, "heavy-handed methods of the past are pressed into service only when the new ones fail to function properly."7 China's velvet prison thus seems to have its origins in the reforms undertaken following Deng Xiaoping's rise to power in 1978. However, as Barmé has noted, Chinese cultural policies in the 1980s were still characterized by a tension between "hard" and "soft" power approaches, as artists and individuals were co-opted into state tutelage but were purged-or even violently repressed-when they stepped outside of tacit boundaries. ${ }^{8}$ While Haraszti acknowledges that this alternation of hard and soft power existed in Eastern Europe, China's hard power continues to manifest itself-albeit in more minor forms-well into the post-Mao period. Chinese society has not been fully coerced into progressive censorship.

China's velvet prison does not, therefore, fully conform to Haraszti's model. The events of June 4 and, more recently, the government crackdown against Falun Gong, serve as important reminders that the state has not fully exchanged "sticks" for "carrots." Generally speaking, however, the past twenty years of Chinese history have not been characterized by the widespread use of brute force to keep the masses in order. In fact, the state has, in many cases, succeeded in co-opting

${ }^{5}$ Geremie R. Barmé, In the Red: On Contemporary Chinese Culture (New York: Columbia University Press, 1999), 7.

${ }^{6}$ Miklós Haraszti, The Velvet Prison: Artists Under State Socialism, trans. Katalin and Stephen Landesmann (New York: Basic Books, 1987), 7.

${ }^{7}$ Ibid.

${ }^{8}$ Barmé, In the Red, 8-9. 
individual desires by "offering responsibility and a constructive role to those people of quality hungry for power."

Where China also differs from the model described by Haraszti is in the presence of a market economy. Like the "directed culture" of state socialism, a market economy also creates limitations:

[An employee's] human rights are severely circumscribedexcept, of course, his right to work. He cannot go outside the walls, he cannot wander at will around the factory, cannot say, or write, or organize whatever he wants. In these matters, it is the firm's interests, conveyed by its owners and managers, that determine right and wrong within the corporate culture... How is this (admittedly simplified) state of affairs different from state socialism? Only one aspect is truly different: the existence of other companies. ${ }^{10}$

With China's reforms and the growth of private corporations subject to market forces and demand, Chinese society is now subject to both the impositions of state ideology and the ideology of commerce-a tension made more dynamic by the state's influence in the market economy. Because of this relationship, state hegemony in post-1989 China might best be conceptualized as a "velvet prison with Chinese characteristics."

\section{Directed Culture: Patriotic Education and National Humiliation}

Although having origins prior to 1989, the structure of China's velvet prison was greatly shaped by the Tiananmen Square protests. Responding to the "June 4 Incident," the CCP undertook a campaign of "cultural rectification." The chaos of June 4 and the events that had unfolded in Eastern Europe throughout 1989 led the Party to conclude that the abandonment of Mao's legacy "was nothing less than political suicide." ${ }^{11}$ Hence, "to renew official ideology and build broad-based national support for the Communist regime" became a central concern

\footnotetext{
${ }^{9}$ Haraszti, 26.

${ }^{10}$ Ibid., 65-66. Parentheses original.

${ }^{11}$ Liu, 55.
} 
for the state in the aftermath of Tiananmen. ${ }^{12}$ Within the Party, however, there was disagreement over how to best reformulate and reassert its ideological influence. On one hand, "conservatives" saw the events of 1989 as a confirmation of their belief that unchecked intellectual liberalization would undermine government authority. ${ }^{13}$ They supported a Neo-Maoist ideology that criticized Deng Xiaoping's market reforms.

Unwilling to sacrifice the goal of economic prosperity, the Party's "reformist" wing aimed to develop a new, cohesive ideology to unify the Chinese populace. ${ }^{14}$ What resulted was an ideology that, while not always consistent with the "revolutionary hegemony" that had long formed the backbone of the state, "retained the discursive formations, the formal and rhetorical features, of Mao's ideology," and wrapped the Party in the cloak of nationalism. ${ }^{15}$ Such an evolution resembles Karl Marx's argument in The Eighteenth Brumaire of Louis Bonaparte. According to Marx, the present was continually infused with the traditions of history. Even revolutionaries, he claimed, attempted to glorify their aims in the language of previous generations. Likewise, the transformation of state hegemony in post-1989 China acted to "conjure up the spirits of the past to their service and borrow from them names, battle cries and costumes in order to present the new scene of world history." 16

Epitomizing the government response to the ideological decay of the 1980s-particularly the political unrest of June 4, 1989-was a state-led campaign of "patriotic education." However, rather than assume the form of overt indoctrination, the campaign to instill Chinese patriotism subtly institutionalized state ideology. This is evidenced by the fact that the educational reforms of the 1990s no longer made the

\footnotetext{
${ }^{12}$ Suisheng Zhao, "A State-Led Nationalism: The Patriotic Education Campaign in Post-Tiananmen China," Communist and Post-Communist Studies 31, no. 3 (1998): 289.

${ }^{13}$ Kalpana Misra, "Curing the Sickness and Saving the Party: Neo-Maoism and Neo-Conservatism in the 1990s," in Chinese Political Culture 1989-2000, ed. Shiping Hua, 133-160 (New York: M.E. Sharpe, 2001), 134.

${ }^{14}$ Ibid.

${ }^{15}$ Liu, 55; Zhao, 289.

${ }^{16}$ Karl Marx, The Eighteenth Brumaire of Louis Bonaparte (New York: International Publishers, 1963), 15-16.
} 
Marxist political science exam a requirement for all college applicants in China. Instead, the state initiated programs like the "I am Chinese" program in universities and a curriculum in all schools that would "portray the Communist state as the embodiment of the nation's will" and "reassert the moral authority of the party." 17

It would be a mistake, however, to say that the patriotic education campaign was purely institutional. Rather, it was a national project that sought to move beyond the "empty slogans" of previous decades and foster a general sense of patriotism that identified the Chinese state with the CCP. ${ }^{18}$ In fact, the campaign epitomized 1990s government propaganda in the sense that reforms that were not strictly consistent with Maoist dogma nonetheless sought legitimacy via appeals to Maoist rhetoric. By doing so, the state was able to garner support from those for whom Maoism was a fundamental historical legacy and incorporate those who, while born into the system, lacked such concrete experience. That the 1990s was also a decade in which the state undertook a dramatic reinvention and restaging of the revolutionary "Red Classics" attests to the fact that the patriotic education campaign was part of a larger movement to rectify a mass culture in support of the CCP. ${ }^{19}$

The reconstruction of state hegemony under the umbrella of patriotism also found much success by drawing upon the narrative of "national humiliation." Prevalent throughout the history of post-Qing China, the discourse of national humiliation "recounts how at the hands of foreign invaders and corrupt Chinese regimes, sovereignty was lost, territory dismembered, and the Chinese people thus humiliated." 20 State portrayals of the events of June 4 were frequently framed by this discourse. Liu Baiyu, a senior party novelist, for example, described the political unrest as a consequence of the "wholesale adoption of Western bourgeois values." ${ }^{21}$ Through this rhetoric, the state not only under-

${ }^{17}$ Zhao, 291-293.

${ }^{18}$ Ibid., 298-299.

${ }^{19}$ Liu, 92-93.

${ }^{20}$ William A. Callahan, "History, Identity, and Security: Producing and Consuming Nationalism in China," Critical Asian Studies 38, no. 2 (2006): 180.

${ }^{21}$ Article appearing in People's Daily, July 8, 1989, translated and quoted in Barmé, In the Red, 21. 
mined charges that posited inherent flaws in the existing governmental structure, but also legitimized itself by using a language that had, by all means, become enmeshed in Chinese culture. In fact, through much of the twentieth century, the discourse of national humiliation had been used to construct a China that needed "saving" and to legitimize rule under Mao and the CCP. ${ }^{22}$ As Barmé has observed, "While Deng is admired for what he has done for the economy, Mao is revered, among other things, for keeping the superpowers, the United States and Soviet Union, at bay." ${ }^{23}$

National humiliation discourse underwent a revival in the 1990s and formed an integral component to the state-led campaign to redirect domestic energies toward a CCP-legitimizing patriotism. This is not only evidenced by the patriotic education campaign's emphasis on the study of Chinese history-especially its modern history of imperial invasion-and its incompatibility with Western democratic ideals, but also by the reemergence of textbooks linking political unrest to national humiliation. ${ }^{24}$ For example, one government textbook read, "Today we are confronted with foreign and domestic enemies who are plotting to force 'peaceful evolution' on our country." 25 These new textbooks were the first of their kind to appear in China since 1947 and were complemented by an array of publications throughout the 1990s that continually invoked national humiliation. ${ }^{26}$ By 2001, the discourse of national humiliation would be institutionalized by the state-declared "National Defense Education Day," which, unlike the previous discourse of national humiliation that promoted the need for a new nationalism, acted to reinforce "proved actions and feelings" in support of the CCP. ${ }^{27}$

${ }^{22}$ Callahan, 183.

${ }^{23}$ Geremie R. Barmé, “To Screw Foreigners is Patriotic: China’s Avant-Garde Nationalists," The China Journal 34 (1995): 213-214.

${ }^{24}$ Callahan, 186.

${ }^{25}$ He Donchang, Wuwang guochi [Never Forget National Humiliation], ed. National Education Committee, Elementary Education Section (Tianjin: Xinlei chubanshe, 1991), 1, translated and quoted in Callahan, 187.

${ }^{26}$ Callahan, 186-187.

${ }^{27}$ Ibid., 201. 
In many ways, post-1989 state policy was effective in fostering a Chinese nationalism that was both fervent and directed outward in the form of negative perceptions of the West. The belief that China's failure to secure the 2000 Olympic Games resulted from Westernparticularly American-bullying stands as one early example in the $1990 \mathrm{~s}^{28}$ While it is true that the awarding of the 2000 Olympic Games to Sydney was tainted by bribery charges, ${ }^{29}$ the assertion of an antiChina conspiracy seems firmly rooted in the discourse of national humiliation. Similarly, the television drama $A$ Beijinger in New York and the publication of books such as China Can Say No and The Plot to Demonize China indicate the growing presence of fervent nationalistic sentiment and the incorporation of Party rhetoric into elements of popular culture during the mid-1990s. This is not to say that individuals were wholly co-opted into the state's ideology, but the appearance of such works indicates that the discourse of state ideology was pervasive. The revival of national humiliation discourse was also evident during the recent celebration of the PRC's $60^{\text {th }}$ anniversary, where usersubmitted comments on the People's Daily website boasted, "Proud to be Chinese! Never again will China be humiliated by foreign powers! China and Taiwan united will never be defeated!"30

The influence of the state on the expression of Chinese nationalism was, perhaps, most visible in the reactions to NATO's 1999 bombing of the Chinese Embassy in Belgrade. In "Tears of Rage: Chinese Nationalist Reactions to the Belgrade Embassy Bombing," Peter Hays Gries presents a number of letters that emerged in Chinese

${ }^{28}$ Peter Hessler, Oracle Bones: A Journey Between China's Past and Present (New York: HarperCollins, 2006), 265; Edward Friedman, "Still Building the Nation: The Causes and Consequences of China's Patriotic Fervor," in Chinese Political Culture, 1989-2000, 103-132 (see note 13), 125.

29 "Olympics-Did \$70,000 in Pledges Buy Votes for Sydney?" The Seattle Times, January 23, 1999, http://community.seattletimes.nwsource.com/archive/?date $=19990$ 123\&slug=2940183 (accessed November 15, 2009).

30 "Blessings to the Motherland," postings on the People's Daily website, $60^{\text {th }}$ Anniversary of the Founding of the PRC, http://english.people.com.cn/90002/ 97623/index.html (accessed November 27, 2009). PRC refers to the People's Republic of China, the government of mainland China which claims to have authority over the island of Taiwan, known formally as The Republic of China on Taiwan. 
newspapers following the Belgrade bombing to argue that the outpouring of passionate-if not angry-nationalistic and patriotic sentiments in the aftermath of the bombing should be viewed as "genuine and understandable" rather than as byproducts of government-sponsored propaganda. ${ }^{31}$ However, while the emotion may have been genuine-and justifiable-the language utilized to express this emotion reflected the state-led patriotic education campaign and the revival of national humiliation discourse.

An article that appeared in the People's Daily, for instance, was clearly framed by the discourse of national humiliation in its emphasis of the continued strength of China in the face of Western aggression:

The wheel of history will not go backward. This is 1999 , not 1899. This is not...the age when people can barge about the world in gunboats...It is not the age when the Western powers plundered the Imperial Palace at will, destroyed the Old Summer Palace, and seized Hong Kong and Macao...China is a China that has stood up; it is a China that defeated the Japanese fascists; it is a China that had a trial of strength and won victory over the United States on the Korean battleground. The Chinese people are not to be bullied, and China's sovereignty and dignity are not to be violated...US-led NATO had better remember this. ${ }^{32}$

Other authors similarly expressed anger over U.S. attempts to humiliate China and argued for China to reassert its sovereignty and take action against the U.S. ${ }^{33}$ While some might contend that the act of Chinese citizens demanding that the state exact an aggressive response is indicative of a "bottom-up" response, these demands nonetheless act to reinforce the notion of the Party as the "national will."

\footnotetext{
${ }^{31}$ Peter Hays Gries, "Tears of Rage: Chinese Nationalist Reactions to the Belgrade Embassy Bombing," The China Journal 46 (July 2001): 26.

${ }^{32}$ Han Zhongkun, "Zhongguo, bushi yibajiujiu [This is Not 1899 China]," People's Daily, May 12, 1999, translated and quoted in Gries, "Tears of Rage," 32.

${ }^{33}$ Gries, "Tears of Rage," 33, 37-40.
} 
The presence of anti-Western patriotism underscored by the discourse of national humiliation is also evident in Peter Hessler's firsthand account in Oracle Bones, which describes protesters shouting "Down with American imperialism!" and directing their anger at local American businesses like McDonald's. ${ }^{34}$ Hessler also recounts conversations with local Chinese who rebuked the United States' perception of itself as a world police power and occasionally brought up the legacy of the Opium War in the midst of venting their anger. ${ }^{35}$

Thus, the reconstruction of state hegemony in the 1990s-what I call a velvet prison with Chinese characteristics-was fundamentally underscored by the ideology of patriotism and national humiliation. Just as Haraszti argues that socialist governments in Eastern Europe utilized "relics" to present themselves as the guardians of tradition, ${ }^{36}$ the CCP has also sought to exercise a monopoly on patriotism in order to direct such sentiment toward state legitimization and the support of Party authority. As seen in incidents like the Belgrade bombing, this policy had a significant impact on public discourse and the shaping of post-1989 culture. However, by invoking the ambiguous ideology of patriotism, the state also created a considerable "gray" area for cultural discourse-one that, by allowing a certain degree of tolerance for dissidents, also allowed individuals to transform the state and, therefore, to challenge the state's attempt to exercise a monopoly on Chinese culture.

\section{The Pragmatic Shift:}

\section{Public Discourse Within The Velvet Prison}

Although the state has acted to reinvent and reassert its hegemonic position, it does not possess a monopoly on cultural construction in post-1989 China. In part, this stems from the nature of the ideology of patriotism, which, as an ambiguous concept, has created a considerable "gray" area for public discourse. While the state has sometimes acted to visibly define the scope of patriotism through the use of force, events in post-1989 China tend to indicate that so long as China's leaders or the

\footnotetext{
${ }^{34}$ Hessler, 14-17.

${ }^{35}$ Ibid., 22.

${ }^{36}$ Haraszti, 111.
} 
authority of the Chinese Communist Party are not publicly attacked, all sorts of discourses are tolerated. ${ }^{37}$

In The Velvet Prison, Haraszti argues that although state socialism prescribes certain rules, the artist is not inherently constrained: "In our eyes the state represents not a monolithic body of rules but rather a live network of lobbies. We play with it, we know how to use it, and we have allies and enemies at the controls." ${ }^{38}$ Likewise, post-1989 Chinese society has also been characterized by discourses articulated in the framework of state ideology. By doing so, individuals in China have been able to exact change on the state itself. Although changes may be minor and incremental, they nonetheless undermine the state's attempt to exercise a monopoly on culture.

There are a number of reasons for the transition to a more "pragmatic dissent" in post-1989 China. A general fear of chaos and disorder seems particularly important. While many have written about the Party's desire to avoid a return to the disorder of the Cultural Revolution or Tiananmen protests, few have acknowledged that the general population also has a vested interest in national stability. Chinese students, for example, became increasingly involved in the Party and less likely to voice idealistic opposition to state policy after the June 4 protests as self-interest and career advancement became predominant factors. ${ }^{39}$ Likewise, economic reform has left many individuals less willing to sacrifice the stability of the state, which is often viewed as an important source of material gain. ${ }^{40}$

Despite being less visible, this pragmatic approach has created profound developments in contemporary Chinese culture. By exploring three particular events-the publication of China Can Say No, the development of "cultural t-shirts," and the "nail house" resistance to

\footnotetext{
${ }^{37}$ Liu, 57,73 .

${ }^{38}$ Haraszti, 78-79.

${ }^{39}$ Luo Xu, "Farewell to Idealism: Mapping China's University Students of the
} 1990s," Journal of Contemporary China 13, no. 41 (November 2004): 783-785.

${ }^{40}$ Bruce J. Dickson, "Dilemmas of Party Adaptation: The CCP's Strategies for Survival," in State and Society in $21^{\text {st }}$-Century China: Crisis, Contention, and Legitimation, ed. Peter Hays Gries and Stanley Rosen, 141-158 (New York: RoutledgeCurzon, 2004), 144. 
government redevelopment-I hope to show how public discourse has operated within China's velvet prison to counter the state's attempts to monopolize Chinese culture.

\section{China Can Say No: Directing Nationalism at the Party}

Published in 1996, China Can Say No criticized Western-particularly U.S.-influence in China and became a major commercial success. Described by Newsweek as "a shrill anti-U.S. polemic," ${ }^{11}$ the book was initially supported by the Chinese government as a genuine reflection of public opinion. ${ }^{42}$ Indeed, China Can Say No was so successful that it spurred a whole wave of "say no" literature that echoed the growing anti-American nationalism emerging in the 1990s. Actively trying to co-opt the discourse into the framework of pro-Party ideology, the state often confined negative reviews of such "say no" literature abroad to places like Hong Kong and Taiwan. ${ }^{43}$

Yet, despite seeming to reflect the state's patriotic and national humiliation rhetoric, China Can Say No undermined the government monopoly on nationalistic discourse. By projecting themselves as the embodiment of popular opinion and making claims that, essentially, made demands of the state, the authors of China Can Say No and other "say no" literature challenged the traditional dominance of the Party. Ben Xu remarks, "While [popular nationalists] direct their attack explicitly against foreigners, the present government is held implicitly to account for yielding too readily to foreign political and commercial demands and for surrendering China's national dignity in the process." ${ }^{24}$ It was this aspect of the "say no" literature that ultimately resulted in an about-face by the state, which openly criticized China Can

${ }^{41}$ George Wehfritz, "Banned in Beijing: The Masses Love Pulp Fiction. Officials Don't," Newsweek, October 28, 1996, http://www.newsweek.com/id/103151 (accessed November 24, 2009).

${ }^{42}$ Peter Hays Gries, "Popular Nationalism and State Legitimation," in State and Society in 21 $1^{\text {st }}$-Century China: Crisis, Contention, and Legitimation, 180-194 (see note 40), 186.

${ }^{43}$ Ibid. 187.

${ }^{44}$ Ben Xu, "Chinese Populist Nationalism: Its Intellectual Politics and Moral Dilemma,” Representations 76 (Autumn 2001): 133. 
Say No in December 1996, cracked down on the proliferation of "say no" literature, and banned the book's sequel, China Can Still Say No. ${ }^{45}$

Although the state ultimately suppressed the "say no" craze, these works still influenced the state's development. Attempting to buttress its position as the embodiment of the nation's will, government efforts to co-opt the expression of popular nationalism simultaneously required the state to infuse itself with "nonofficial discourse." After reversing its position on China Can Say No, for example, the Party sought "to persuade the people to let the Party maintain its leading role in Chinese nationalism and foreign policy-making." 46 The publication of China Should Not Play 'Mr. No', for instance, praised the "righteous anger" of popular nationalists while also claiming that "emotion cannot substitute for policy." ${ }^{47}$ While proclaiming the ultimate authority of the state, the response's legitimization of popular nationalism also undermined the government's claim to a monopoly on cultural construction-although citizens could not make policy, they could enter the debate of nationalism and exert pressure on the state.

\section{"Cultural T-shirts": Wearing the Nonofficial}

Predating the "say no" craze, the appearance of so-called "cultural tshirts" in Beijing in the early 1990s demonstrates the ability of "dissident" discourses to affect the state. The cultural t-shirts that appeared in 1991 were largely the work of entrepreneur-artist Kong Yongqian. Although he insisted that his widely successful t-shirt designs were not intended to be politically provocative, Kong's shirts, in effect, used "nonofficial colloquial language to communicate sentiments that many people shared but were unable to give voice to in public." ${ }^{48}$ In this regard, Kong's shirts were an undeniably populist and nationalistic project.

In June of 1991, Kong was detained for questioning by the Chinese police, who told him that his shirts were the most serious political

\footnotetext{
${ }^{45}$ Gries, "Popular Nationalism and State Legitimation," 188.

${ }^{46} \mathrm{Ibid}$.

${ }^{47}$ Ibid.

${ }^{48}$ Barmé, In the Red, 149.
} 
incident in Beijing since June 4, 1989. ${ }^{49}$ His shirts were subsequently banned and his unsold merchandise was confiscated and destroyed. Yet, in the face of government opposition, Kong defended his shirts with patriotic language, arguing that he was simply trying to create an inexpensive product that reflected Beijing sentiments rather than those of Hong Kong, Taiwan, or the United States. ${ }^{50}$

However, Kong's t-shirts still possessed a populist element that profoundly threatened the state. According to Geremie Barmé:

The shirts would also provide people with an opportunity to release pent-up emotions and frustrations, regardless of whether they were personal, social, or political. It was this dimension of the $\mathrm{t}$-shirt craze-that of a popular, unspoken conspiracy of self-expression writ in large in satirical and ironic terms-that the authorities may well have found unsettling. ${ }^{51}$

As a "passive" mode of expression, Kong's shirts allowed people to vent their opinions in a safe, non-confrontational manner that made it difficult for government authorities to silence. Moreover, by informalizing individual expression and allowing individuals to have control over nationalistic expression-in ways that often satirized official state rhetoric-Kong's shirts significantly undermined the Party's control over national identity discourse and weakened its ability to impose an ordered, cohesive national identity.

From the state's perspective, Kong's t-shirt designs were not only a challenge to state authority, but were also harmful to socialist morality. While detained, Kong's interrogators scrutinized every detail of his designs, whether it was imagery that, they felt, projected the state as evil or his orientation of a particular Chinese character that they believed to be a reference to the Cultural Revolution. ${ }^{52}$

\footnotetext{
${ }^{49}$ Ibid., 145.

${ }^{50}$ Ibid., 151.

${ }^{51}$ Ibid. 156.

${ }^{52}$ Ibid.,161-162.
} 


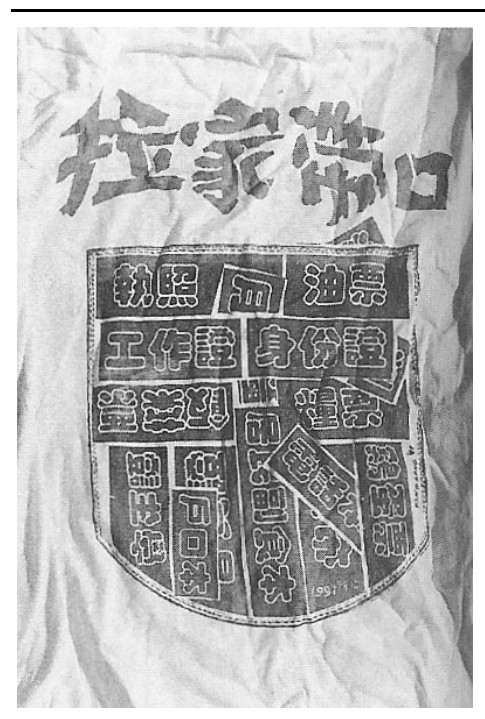

Fig. 1: "Making Ends Meet." A T-shirt design by Kong Yongqian. (Photograph by Lois Conner, from Geremie R. Barmé, In the Red: On Contemporary Chinese Culture. New York: Columbia University Press, 1999 [Photo Insert].)

The t-shirt "Making Ends Meet," which featured a large pocket containing documents such as a monthly bus pass, cloth and grain rations, meal tickets, a name card, and a secret bank account record, was of particular concern to the police, who accused Kong of being an antigovernment activist. Suspicious of his inclusion of outdated government documents, many of which dated from the Mao period, the police chided, "You're resentful of the government's long-term policies, aren't you?...Why do you despise the socialist system so much?" 33 While Kong defended his design and the inclusion of such outdated documents as an act of nostalgia, his work can nonetheless be seen as subversive for recalling images of China's more austere past during a period in which the state preferred to emphasize the population's dramatic material gain. In a similar manner, other $t$-shirt designs also subverted government ideology by borrowing commonly used government catch Red, 162 .

${ }^{53}$ Kong Yongqian, unpublished manuscript, translated and quoted in Barmé, In the 
phrases-often satirizing official responses to the June 4 protests in the process - and by highlighting elements of Chinese society that officials often denied or preferred to ignore.

Kong's shirts were eventually removed from the market, but, curiously, he was released from detainment after paying a small fine-a seemingly minor punishment for what the police had called the most serious political incident since the 1989 Tiananmen Square protests. Meanwhile, similar, though less provocative shirts remained on the market. In fact, the government even tried to co-opt the t-shirt craze in support of its bid for the 2000 Summer Olympics. However, the "barbed cynicism" still persisted in these cultural t-shirts and thus gradually became enmeshed within mainstream culture. While the "dissidence" may have been scaled back, these shirts nonetheless weakened state control on cultural construction and forced the state to accommodate exhibitions of individuality that had emerged outside of official culture.

\section{"I Have a Responsibility to Protect this Place": Challenging China's "Urban Renewal”}

Urbanization and "urban renewal" have been defining features of China's road to "modernization" as the state has sought to remove "impediments to progress" and transform China "from a backward agricultural country" into an advanced industrial nation. ${ }^{54}$ In the years leading up to the 2008 Summer Olympics, Western media became fascinated by the wave of redevelopment sweeping across China. Images such as the Chongqing "nail house" were depicted as embodying "the discontent of people who are suddenly uprooted, told that they must make way for a new skyscraper or golf course or industrial zone." 55 In fact, The New York Times found the Chongqing nail house unusual for the reason that the owners were able to "hold out" for so long in a

${ }^{54}$ Hessler, 179; “Urbanization Makes Life Better," People's Daily, August 27, 2009, http://english.people.com.cn/90001/90780/91342/6741524.html (accessed November $28,2009)$.

${ }^{55}$ Howard W. French, "Homeowner Stares Down Wreckers, at Least for a While," The New York Times, March 27, 2007, http://www.nytimes.com/2007/ 03/27/world/asia/27china.html (accessed November 25, 2009). 


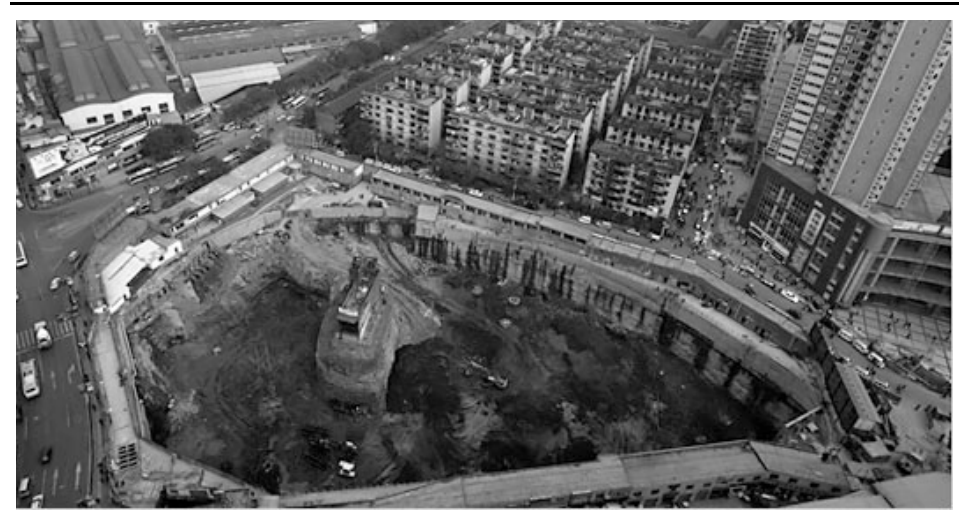

Fig. 2: A "Nail House" in China's Chongqing Municipality. (Photograph by China Photos/Getty Images, from Howard W. French, "Homeowner Stares Down Wreckers, at Least for a While," The New York Times, March 27, 2007, http://www.nytimes.com/2007/03/27/world/asia/27china.html [accessed November 25, 2009].)

country where many were arrested or even beaten for protesting eviction from their homes. ${ }^{56}$

However, what is most intriguing is not that they resisted so visibly, but how they framed their resistance. When asked about her resistance by the China Daily, owner Wu Ping boldly stated, "I wanted to safeguard my dignity and lawful rights." ${ }^{57}$ Coupled with the fact that the owners waved the PRC flag atop their home, the struggle emerged as a form of patriotism. The owners projected themselves not as opponents of the state, but as fighting to uphold the integrity of the state by using the law to obtain adequate compensation for a house that had been passed down through generations.

Peter Hessler provides a similar example in his profiling of Zhao Jingxin's struggle to resist the demolition of his home in an old butong neighborhood. Like the owners of the "nail house," Zhao justified his resistance in patriotic rhetoric, exclaiming, "This house is older than the

${ }^{56}$ Ibid.

57 “'Nail house' in Chongqing Demolished," China Daily, April 3, 2007, http://www.chinadaily.com.cn/china/2007-04/03/content_842221.htm (accessed November 25, 2009). 
United States of America!"58 It was not a matter of money, Zhao explained to Hessler, "As a Chinese person, I have a responsibility to protect this place. I won't leave willingly." 59

Zhao's suit against the government was one of many that occurred in the late 1990s. According to Hessler, successful suits received prominent coverage as a sign of government fairness. However, most failed and were never heard about in the public sphere. ${ }^{60}$ Irrespective of the inconsistent government response, the fact that citizens were able to use state rhetoric to question the government for the sake of their own personal interest represents a challenge to the state's control over patriotic and cultural discourse. Not only must the state co-opt discontent through material reward (e.g., a new apartment and lofty financial compensation), but the state must also respond to challenges that demand that it to exemplify the rhetoric it has propagated to fortify its own legitimacy. That the proliferation of "nail house" protests spurred the passage of a new property law in 2007 indicates the extent to which the individual's use of state rhetoric against the state has forced the Party to make incremental changes in order to maintain its hegemonic position. $^{61}$

\section{CUlTure COMMERCIALIZED: ForCES OF A MARKET ECONOMY}

Of the major trends in post-1989 China, the emergence of a vibrant market economy has been among the most visible and profound. While Deng Xiaoping tried to downplay the ideological contradictions of creating a quasi-capitalist system in a socialist state, the introduction of a market economy nevertheless exerts new forces on China that act on both the state and society.

Liu Kang has described popular commercial culture in China as a "new battleground" of culture and ideology wherein battles are waged

\footnotetext{
${ }^{58}$ Hessler, 177.

${ }^{59}$ Ibid., 178.

${ }^{60}$ Ibid., 181.

${ }^{61}$ "'Nail House' Owner Receives Millions of Yuan in Compensation," China Daily, September 30, 2007, http://www.chinadaily.com.cn/china/2007-09/30/content_614 9005_2.htm (accessed November 25, 2009).
} 
through "symbolic acts." ${ }^{62}$ Similarly, Arif Dirlik has pointed out that China's economic reforms have "changed life at the everyday level in transforming the habits of consumption-of culture no less than the commodities of everyday life." ${ }^{63}$

In addition, economic reform has significantly altered the ways in which citizens interact with the government. The state's pragmatic approach towards economic development-which has, by all means, become a form of performative legitimacy — has allowed a considerable degree of freedom that influences not only the state-society relationship, but also the ways in which traditional state ideology is received. As Liu argues, "Political demystification and economic decentralization have drastically reduced the authority of the CCP leadership... [state ideology] is reduced to nothing more than political rhetoric in an increasingly pluralistic society." ${ }^{64}$

Yet, state influence still pervades commercial culture. The success of foreign corporations in China, for example, has simultaneously produced both "Westernization" and resistance. Reflecting the post-1989 nationalistic fervor, many Chinese have sought to develop competing brands and enterprises that more accurately reflect the "Chineseness" of economic reform. ${ }^{65}$ In this regard, the forces of the market economy have become enmeshed into the construction of cultural identity and may come into conflict with the ideology of state-led patriotism and fears of renewed national humiliation.

\section{Symbolic Battles: Ideology and Advertisement}

A significant result of China's market reforms has been the growth of private advertising. While advertising is often a manipulative act, Barmé has observed that in China, "[targeted advertising] was a marked contrast to the previous ways in which people were targeted"-commercial culture created a sense of "consumer empowerment" in which the

\footnotetext{
${ }^{62}$ Liu, 84.

${ }^{63}$ Arif Dirlik, "Markets, Culture, and Power: The Making of a 'Second Cultural Revolution' China," Asian Studies Review 25, no. 1 (March 2001): 1.

${ }^{64}$ Liu, 57.

${ }^{65}$ Beverly Hooper, "Globalisation and Resistance in Post-Mao China: The Case of Foreign Consumer Products," Asian Studies Review 24, no. 4 (December 2000): 450-453.
} 
consumers felt less like a product of state propaganda and more like an individual being catered to. ${ }^{66}$ However, consumer culture in China was neither a byproduct of propaganda nor a triumph of individualistic market forces. Instead, it became a realm of hybridized culture in which state rhetoric was present but often refashioned for the purposes of material gain.

While market reforms diminished the role of the state in the economy, the state has not remained neutral. In fact, it has often acted to funnel commercial culture into areas that reinforce state objectives. Jing Wang, for example, argues that "weekend culture in China is first and foremost an official discourse born from well-calculated state policy." 67 With the emergence of a number of consumer publications in the mid1990s, the state acted to "[educate] the masses about how to consume cultural and commodity goods, and, above all, how to consume leisure itself." ${ }^{\prime 8}$ Augmented by the introduction of a forty-hour workweek, the state's leisure discourse promoted activities requiring capital expenditure in order to develop a culture of consumption that furthered economic growth and affirmed the Party's role as a competent government. It was a culture that promoted "lifestyle shopping" and, infused with the ideologies of patriotism and national humiliation, became the source of the "modern construction of the spiritual civilization." 69

However, as the state has acted to maintain its hegemonic position in post-1989 China, it has had to compete with trendier elements of global commercial culture that tend to enjoy greater mass appeal. In response, the state has tried to "modernize" its messages, using, in one particular case, neon slogan boards, computer images, and ad displays in Beijing to deliver the messages of a new "spiritual civilization" campaign. ${ }^{70}$ Influenced by the nearby success of "Kong-Tai" culture, the

\footnotetext{
${ }^{66}$ Barmé, In the Red, 238.

${ }^{67}$ Jing Wang, "Culture as Leisure and Culture as Capital," positions: east asia cultures critique 9 , no. 1 (2001): 73.

${ }^{68}$ Ibid., 74.

${ }^{69}$ Barmé, In the Red, 240-241; Wang, 80.

${ }^{70}$ Barmé, In the Red, 244.
} 
state sought to refashion itself through new corporate identities, "modernized" journalism, and mainstream appeal. ${ }^{71}$

But, just as the Party tried to further its appeal through commercial culture, commercial culture has manipulated state rhetoric in order to make a profit. An insecticide, for example, was advertised using language from a 1963 poem written by Mao, proclaiming, "Away with all pests!"72 In a similar manner, a vacuum commercial remarked, "dust won't disappear of its own accord," a clear reference to Mao's declaration that reactionaries would have to be swept away like dust. ${ }^{73}$

While it is not unusual for companies to employ official discourse for their own profit, the reformulated rhetoric in China is profound in that its use is fundamentally at odds with its ideological significance. On one hand, this reinforces the strength of the Party as part of society's collective consciousness, but it also makes state rhetoric subject to the needs of individuals and diminishes its inherent meaning. While the Party remains in a position of authority, the symbols of its hegemony become malleable as the state, the market, and the individual construct their own cultural niches.

\section{CONCLUSION}

China's cultural development since 1989 has thus been underscored by a complex interaction between the state, society, and the market. I have argued that this relationship can be conceptualized as "a velvet prison with Chinese characteristics." The events of Tiananmen Square have undoubtedly been significant in the construction of this velvet prison. In the aftermath of June 4, the state-that is, the Chinese Communist Party-acted quickly to reassert its claim to hegemony by utilizing the discourse of patriotism and by reviving the rhetoric of national humiliation.

While the state has been reasonably successful in establishing and maintaining its legitimacy, the ambiguous nature of its new hegemonic

${ }^{71}$ Ibid., 245. "Kong-Tai" culture refers to the commercial culture of Hong Kong and Taiwan.

${ }^{72}$ Ibid., 250. Mao's poem was entitled "Reply to Comrade Kuo Mo-Jo."

${ }^{73}$ Ibid. 
ideology, combined with the forces of economic reform, has allowed a considerable degree of individual freedom that has ultimately undermined the state's ability to exercise a monopoly on the development of culture. Hence, while the state tries to control the evolution of Chinese culture from "the top," individuals and economic forces simultaneously affect the state, resulting in new relationships that redefine the role of the state and the ways in which the populace understands its ideology.

Moreover, the success of the penetration of state ideology has been a double-edged sword. While the diffusion of patriotic and national humiliation based discourses have often been useful in developing a pro-government mentality, groups and individuals have been able to use official ideology to make demands of the state and challenge the legitimacy of the state's claims.

The CCP's recent commitment to the development of a "harmonious society" attests to the changing nature of state power. Although "harmonious society" may imply a silencing of dissidence, harmony is also a concept based upon the synthesis of different elements. While this does not include "dissonant" elements, it does represent a departure from previous generations that sought to impose a monolithic cultural and economic order. In this regard, it seems that China's future will be marked by the continued interaction of "a live network of lobbies" that further transform Chinese culture within the framework of China's velvet prison. 


\section{BIBLIOGRAPHY}

“56 Columns of Ethnic Groups Unity installed on Tiananmen Square." People's Daily, September 15, 2009. http://english.people.com.cn/90001/90783/ 91300/6757794.html (accessed November 27, 2009).

Barmé, Geremie R. In the Red: On Contemporary Chinese Culture. New York: Columbia University Press, 1999.

- - " "To Screw Foreigners is Patriotic: China's Avant-Garde Nationalists." The China Journal 34 (1995): 209-234.

"Blessings to the Motherland." Postings on the People's Daily website. $60^{\text {th }}$ Anniversary of the Founding of the PRC. http://english.people.com.cn/ 90002/97623/index.html (accessed November 27, 2009).

Callahan, William A. "History, Identity, and Security: Producing and Consuming Nationalism in China." Critical Asian Studies 38, no. 2 (2006): 179-208.

Chinese Political Culture, 1989-2000. Edited by Shiping Hua. New York: M.E. Sharpe, Inc., 2001.

Dickson, Bruce J. "Dilemmas of Party Adaptation: The CCP's Strategies for Survival." In State and Society in $21^{\text {st }}$-Century China: Crisis, Contention, and Legitimation, 141-158.

Dirlik, Arif. "Markets, Culture, and Power: The Making of a 'Second Cultural Revolution' China.” Asian Studies Review 25, no. 1 (March 2001): 1-33.

French, Howard W. "Homeowner Stares Down Wreckers, at Least for a While." The New York Times, March 27, 2007. http://www.nytimes.com/ 2007/03/27/world/asia/27china.html (accessed November 25, 2009). 
Friedman, Edward. "Still Building the Nation: The Causes and Consequences of China's Patriotic Fervor.” In Chinese Political Culture, 1989-2000, 103132.

Gries, Peter Hays. "Popular Nationalism and State Legitimation." In State and Society in 21't-Century China: Crisis, Contention, and Legitimation, 180194.

- - . "Tears of Rage: Chinese Nationalist Reactions to the Belgrade Embassy Bombing." The China Journal 46 (July 2001): 25-43.

Haraszti, Miklós. The Velvet Prison: Artists Under State Socialism. Translated by Katalin and Stephen Landesmann. New York: Basic Books, 1987.

Hessler, Peter. Oracle Bones: A Journey Between China's Past and Present. New York: HarperCollins, 2006.

Hooper, Beverly. "Globalisation and Resistance in Post-Mao China: The Case of Foreign Consumer Products." Asian Studies Review 24, no. 4 (December 2000): 439-470.

Kristof, Nicholas D. "Beijing Death Toll at Least 300; Army Tightens Control of City by Angry Resistance Goes On." The New York Times, June 5, 1989.

Liu, Kang. Globalization and Cultural Trends in China. Honolulu: University of Hawaii Press, 2004

Marx, Karl. The Eighteenth Brumaire of Louis Bonaparte. New York: International Publishers, 1963.

Misra, Kalpana. "Curing the Sickness and Saving the Party: Neo-Maoism and Neo-Conservatism in the 1990s." In Chinese Political Culture 1989-2000, 133-160. 
“"Nail house' in Chongqing Demolished." China Daily, April 3, 2007. http://www.chinadaily.com.cn/china/2007-04/03/content_842221.htm (accessed November 25, 2009).

“Nail house' Owner Receives Millions of Yuan in Compensation." China Daily, September 30, 2007. http://www.chinadaily.com.cn/china/200709/30/content_6149005_2.htm (accessed November 25, 2009).

“Olympics-Did \$70,000 in Pledges Buy Votes for Sydney?" The Seattle Times, January 23, 1999. http://community.seattletimes.nwsource.com/archive/ ?date $=19990123 \&$ slug $=2940183($ accessed November 15, 2009).

State and Society in 21 $1^{\text {st }}$-Century China: Crisis, Contention, and Legitimation. Edited by Peter Hays Gries and Stanley Rosen, 141-158. New York: RoutledgeCurzon, 2004.

“The Tank Man." Directed by Antony Thomas. Frontline, PBS, April 11, 2006. Available online at http://www.pbs.org/wgbh/pages/frontline/tankman/ (accessed November 7, 2009).

“Urbanization Makes Life Better." People's Daily, August 27, 2009. http://english.people.com.cn/90001/90780/91342/6741524.html (accessed November 28, 2009).

Wang, Jing. "Culture as Leisure and Culture as Capital." positions: east asia cultures critique 9, no. 1 (2001): 69-104.

Wasserstrom, Jeffrey N. “Tiananmen's Shifting Legacy.” In China in 2008: A Year of Great Significance, edited by Kate Merkel-Hess, Kenneth L. Pomeranz, and Jeffrey N. Wasserstrom, 135-140. New York: Rowman and Littlefield Publishers, Inc., 2009.

Wehfritz, George. "Banned in Beijing: The Masses Love Pulp Fiction. Officials Don't." Newsweek, October 28, 1996. http://www.newsweek.com/id/ 103151 (accessed November 24, 2009). 
$\mathrm{Xu}$, Ben. "Chinese Populist Nationalism: Its Intellectual Politics and Moral Dilemma." Representations 76 (Autumn 2001): 120-140.

Xu, Luo. "Farewell to Idealism: Mapping China's University Students of the 1990s." Journal of Contemporary China 13, no. 41 (November 2004): 779799.

Zhao, Suisheng. "A State-Led Nationalism: The Patriotic Education Campaign in Post-Tiananmen China." Communist and Post-Communist Studies 31, no. 3 (1998): 287-302. 